\title{
Analysis of Business Opportunities and Threats in The Household Cleaners Sub-Sector of The Chemicals Industry in Indonesia
}

\author{
Miftah Faris and Budi Rahardjo
}

\begin{abstract}
A thriving chemical industry, opens opportunities for small entrepreneurs to compete in this industry, especially for household cleaning products. The global household cleaners market is expected to record a CAGR of 5.7\% over the forecast period, 2018-2023. Competition for household cleaners is the most visible competition in the chemical industry. To remain competitive, companies are required to provide solutions to environmental problems through the development of green products. Environmental awareness in the community has also increased due to government support and intensive go-green campaigns.

This paper presents an analysis of the external condition in the household cleaning market that is able to bring small and medium-sized companies to grow larger and is also able to compete in the current household cleaning industry. Therefore, the purpose of this study is to determine the condition of the household cleaning market in Indonesia and to help business people formulate their strategic policies. The approach to be used in this study with external analysis consisting of PESTEL analysis, Porter's 5 Force, and Customer Analysis.
\end{abstract}

Index Terms-Household Cleaner Market, External Analysis, PESTEL, Porter's 5 Force, Customer

\section{INTRODUCTION AND RESEARCH OBJECTIVES}

Chemistry's in everything and it's everywhere. By its very nature, everything around us, from air and water to the products and technologies that use every day, even our own living tissue is chemistry in motion. The application of chemistry will help improve safety, health and productivity. More than $96 \%$ of all goods produced are directly touched by chemistry, either as a material or in processing. Including indirect support, chemistry touches $100 \%$ of manufactured goods. ${ }^{[1]}$

High contribution of the chemical industry to global GDP and GDP in Indonesia, this gives the view that chemistry is still a necessity that cannot be separated from life. In business this is a good opportunity for entrepreneurs in the chemical sector and socially the chemical industry can absorb a large workforce. On the other hand, the chemical industry is considered as one of the sectors that are ready to enter the industrial era 4.0. The sector has become one of the leading and priority of the Indonesian government in industry 4.0..$^{[3]}$ The growing chemical industry, opening up opportunities for small and new entrepreneurs to compete in this industry, especially for household cleaners products. The global household cleaners market is expected to register a CAGR of $5.7 \%$ during 2018 to 2023. [2]

Published on February 8, 2020.

Miftah Faris, Institut Teknologi Bandung, Indonesia.

(e-mail: miftah_faris@sbm-itb.ac.id)

Budi Rahardjo, Institut Teknologi Bandung, Indonesia.

\section{A. Statement of the Problem}

The competition for the household cleaner can be said to be the most visible competition in the chemical industry because it is in direct contact with the whole society. The number of competitors is a consideration for entrepreneurs to enter in a very tight competition. But the development of information technology in the industrial era 4.0 is very rapidly developing and tends to disrupt the market. Small to large business activities take advantage of this development to run their business. Industrial era 4.0. can be an advantage for small entrepreneurs to compete but the challenges faced are very difficult because household cleaners products from large companies in Indonesia already have a strong brand image and even that reach top brands are the same company for years to date.

In addition, in order to remain competitive in the midst of intense market competition, business people are required to provide solutions in dealing with various environmental problems that have arisen through developing green products. The condition of the intensity of the competition will be analyzed using PESTEL analysis and Porter's 5 Force, then customer analysis is performed to see the factors that influence the purchasing decision. The results of the analysis are expected to be considered by entrepreneurs to make strategic policies in the future.

\section{B. Research Objectives}

This study aims to see how opportunities and threats will be faced by small and medium-sized companies who want to compete in the household cleaning industry. In addition, this study aims to determine customer preferences in choosing household cleaning products and what factors can influence the customer's decision to buy chemical product aids. This research is also expected to answer whether the value of environmentally friendly household cleaning products can influence purchasing decisions. This provides a view of the customer's concern for the environment and how well they are educated about environmentally friendly chemical products. The results of this research are expected to provide solutions in solving problems and formulating business strategies effectively and efficiently.

\section{RESEARCH METHODOLOGY}

In this research, the authors used a quantitative method with the type of survey method with a descriptive research approach and qualitative methods with a closed interview. Survey conducted by distributing questionnaires containing questions (based on theory) aimed at answering research questions. The population in this research is Indonesian people living in Jakarta and West Java. The two provinces 
also have an index of human development and people's purchasing power that is above the average province in Indonesia. For this reason, populations from Jakarta and West Java are suitable as research populations.

Quantitatively, this research uses multiple logistic regression with six independent variables for customer analysis. The qualitative method used in this research was carried out after the questionnaire or survey data collection process was completed. Qualitative data collection techniques here use observation and interviews.

\section{EXTERNAL ANALYSIS}

\section{A. PESTEL Analysis}

There are several macro-economic factors that can have a profound impact on company performance. In certain situations, these macroeconomic factors need to be analyzed carefully to determine how big the role of these factors is in the company's success. PESTLE Analysis provides a framework that can be used to investigate macroeconomic factors by analyzing their involvement. The types of questions used include political aspects, economic factors, cultural aspects, technological innovations, applicable laws and environmental considerations.

\section{Political}

The Ministry of Industry of the Republic of Indonesia focuses on a number of hazards that can arise from mistakes in handling chemicals, including fire, explosion, irritation, and environmental pollution. Quality demands make every industry implement emergency response schemes. The number of mistakes in handling chemicals makes the government very strict with licensing even though organic chemicals make the conditions for building a chemical industry more difficult.

On the other hand, the chemical industry has become one of the priority sectors focused by the government based on the Making Indonesia 4.0 road map. This is to strengthen and deepen the structure of manufacturing, and create integrated industries from upstream to downstream in the country. ${ }^{[3]}$ This is an excellent opportunity for domestic industrial companies to develop and expand markets in order to compete with international companies.

\section{Economy}

Economic factors such as macro and micro will have an impact on customer purchasing power. The indicator that is most easily seen to measure whether people's purchasing power is a change in the price level. Changes in the price of the macroeconomy are influenced by inflation. Inflation in Indonesia over the past 5 years has tended to move stably. The Central Statistics Agency releases inflation data on an annual basis, inflation for September 2019 was recorded at 3.39 percent (YoY), lower than the August 2019 inflation of 3.49 percent (YoY) and declined again in October 2019 at 3.13 percent (YoY) ${ }^{[4]}$ Controlled inflation is influenced by core inflation that is maintained, Bank Indonesia's policy consistency in maintaining price stability, wellmanaged aggregate demand, exchange rates that move in accordance with its fundamentals, and the effect of minimal global prices. ${ }^{[5]}$
Household consumption which grew by 5.01\% per quarter III / 2019 and only slightly adrift compared to quarter III / 2018 (last year) which grew 5.0\% shows that consumption has tended to slow down lately. Consumer surveys as of October 2019 released by BI show that the tendency of people to save is even higher compared to September 2019. The portion of savings to income as of October 2019 increased from 19.4\% in the previous month to $19.8 \%$. The portion of income used for consumption decreased from $68 \%$ in September 2019 to $68.8 \%$. This data shows that at the end of 2019 people tend to reduce their consumption, but that does not mean that purchasing power is declining, it's just that people prefer to save their income as savings.

\section{Social}

Social factors include all factors that can affect the needs of customers and affect the size of the existing market share. Household cleaners have become a necessity in every household, but there are still factors that affect these needs such as concern for health and hygiene. Health problems and hygiene campaigns are getting more intensive by the public. The large market share of household cleaners is clearly reflected in the number of households in Indonesia.

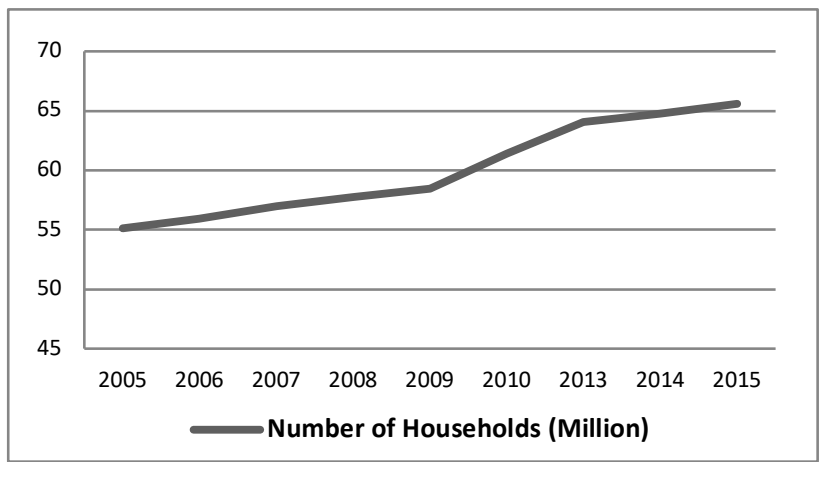

Figure 1: Number of Households in Indonesia (2005-2015)

Household growth in Indonesia for 10 years has continued to increase and this trend continues to this year. ${ }^{[6]}$ The number of households owning their own homes is quite large, reaching 80.02 percent in 2018. This size of the market share represents an opportunity for entrepreneurs in this industry to develop.

4. Technological

An increasing number of environmental conservation campaigns and government regulations regarding the impact of waste on the environment have led to the development of new methods in the industrial world with green manufacturing. The increasingly stringent regulations and laws on environmentally-friendly industries, as well as increasing consumer awareness to use environmentally friendly products at low prices, causes the industrial world to become more serious in handling environmental problems and integrating environmental aspects at all stages of the company's processes. Even so, industries that implement green are relatively small compared to the number of existing industries, especially in developing countries. ${ }^{[7]}$ 
On the other hand, the lifestyle of humankind throughout the world also experienced a drastic change in the period of Industry 4.0. In the past, many people in the world only used computers and the internet to communicate, now in Industry 4.0 computers and the internet have become part of all aspects of daily human life, ranging from communicating, working, studying, shopping, entertainment, and so on. The once-long distribution chain of manufactured goods throughout the world is now cut short. Because, many manufacturing companies around the world have begun to reach their end-user products through digital marketing. This can be an opportunity for small and medium-sized companies to compete with top brands, but currently the household cleaning market is still led by the store-based distribution channel. ${ }^{[2]}$

\section{Environment}

Environmental factors can be used when doing strategic planning or trying to influence buyer decisions such as geographic location factors. Geographically, the location of chemical industry production, both organic and inorganic, is regulated in the Government Regulation of the Republic of Indonesia No. 107 of 2015 article 4 concerning industrial business licenses stating that "industrial business licenses are granted to industrial companies whose industrial business activities are located in industrial designations" . This regulation is a step taken by the government to prevent the occurrence of environmental damage that can have an impact on settlements around the factory. ${ }^{\left[{ }^{[3}\right.}$ However, this factor makes it difficult for household-scale companies to enter the chemical industry.

In addition, another environmental factor is the government's policy regarding environmentally friendly products. the Ministry of Environment and Forestry (KLHK) introduces policies and procedures for applying environmentally friendly labels for the procurement of environmentally friendly goods and services. This policy is directed at efforts to improve environmental performance, efficient use of natural resources while increasing product competitiveness. This program is expected to have a domino effect on changing consumption patterns and green lifestyle, increasing innovation and environmentally friendly investment, and growing capacity of the environmentally friendly product industry. As we know that household cleaners are still dominated by chemical content, this policy provides space for the household chemicals industry to innovate to create environmentally friendly products.

\section{Legal}

Legal factors include legal influences such as changes in existing or future laws. The law that affects household cleaning products is product legality, this is very important before a company markets its products. In the latest regulation the Ministry of Health No. 26 of 2018, article 19 states that the permission of a Household Company for Household Health Supplies can be granted to individuals or non-individuals. Household Health Supplies, hereinafter referred to as PKRT, is a tool, material, or mixture of materials for maintenance and care for human health, intended for use in households and public facilities. Medical Device and PKRT Domestic Work Permit is a permit given to household companies that have fulfilled the requirements to produce Medical Devices and / or PKRT and have received counseling from provincial health workers. ${ }^{[9]}$

Another legality that must be fulfilled besides the Ministry of Health Regulation is Industrial Business License. Industrial Business License is an operational permit granted to every person or entity to carry out business activities in the field of industry which processes raw material into a product with a new composition and specifications. According to Government Regulation No.107 / 2015, Industrial Business Permits are required for each industrial business actor and are classified according to business scale (ie Small, Medium and Large). To enlarge the scale of production sites, Industrial Business Licenses are a necessity and need to fulfill administrative requirements that are often required in various business collaborations. Industrial Business Permit is one of the requirements to obtain a BPOM Distribution License, which is a marketing authorization for food products, cosmetics, and medicines. ${ }^{[8]}$

\section{B. Porter's 5 Forces}

The particular configuration of Porter's five forces tells immediately how the industry "works," how creates and shares value. It explains the industry's profitability. These five forces including the intensity of rivalry among existing competitors, the bargaining power of buyers, the bargaining power of suppliers, the threat of substitutes, and the threat of new entrants. The results of the porter five force analysis in figure 2.

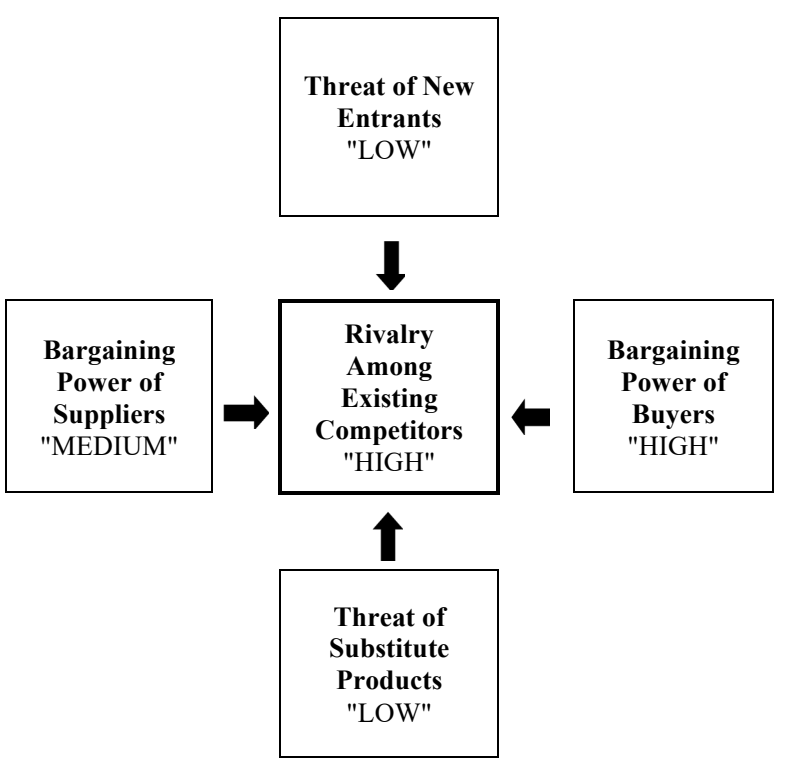

Figure 2: Porter Five Force Analysis Result

Threat from new arrivals and substitute products at low levels and power suppliers at medium levels. However, rivalry and buyer power have a high level, thereby reducing the level of profitability in this industry. The conclusion from the analysis is that the current conditions in the household cleaning industry still have good profitability but for newcomers it is quite difficult to be able to compete in the industry. 


\section{CUSTOMER ANALYSIS}

Researchers will describe the results of a questionnaire regarding consumer perceptions of household cleaning products. Looking at the characteristics of respondents (figure 3) is intended to determine whether the respondent represents the company's target market and provides answers that can significantly influence the question factors.

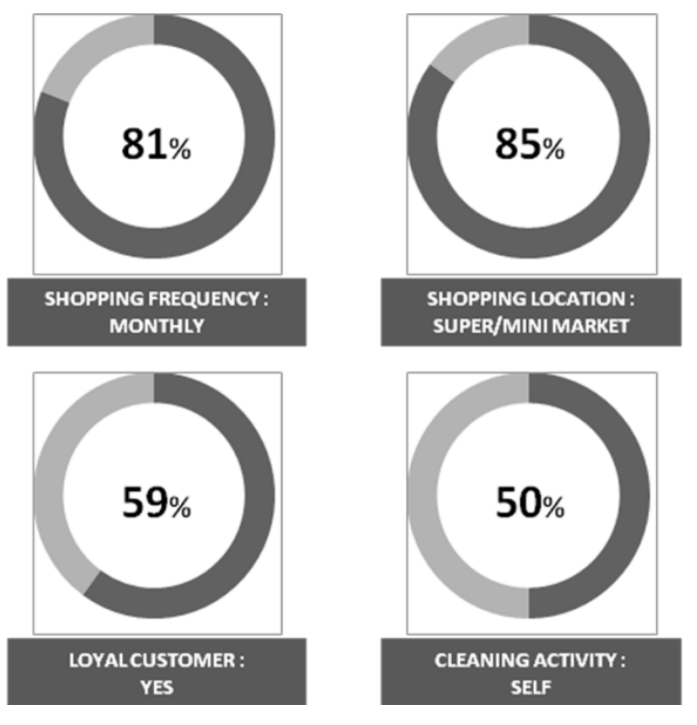

Figure 3: Respondent Characteristic

Based on the consumer behavior model there are 2 stimuli that influence purchasing decisions, the first is stimulation in terms of marketing in the form of a marketing mix and the second is other stimuli outside marketing namely economics, politics, and culture. ${ }^{[10]}$ Previously the economy and politics had already been discussed in the PESTEL analysis. In this customer analysis to determine the factors that influence the decision to buy household cleaning products seen by the marketing mix or commonly called 4P's. The Marketing mix factors used to be independent variables that will affect the purchasing decisions of respondents as the dependent variable. The independent variables are Product (Brand, Quality, and Legal), Place, Price, and Promotion. Meanwhile, the dependent variable is dichotomous like a dummy variable, 1 to state that the respondent buys and 0 to declare not to buy. To see how significant the influence of independent variables on the dependent variable using logistic regression.

Table 1: Influence of Purchasing Decision Factor

\begin{tabular}{|l|c|c|l|}
\hline \multicolumn{1}{|c|}{ VARIABLES } & SIG. & $\begin{array}{c}\text { ODDS } \\
\text { RATIO }\end{array}$ & \multicolumn{1}{c|}{ RESULT } \\
\hline LEGAL (X1) & 0,006 & 10,577 & Significant \\
\hline PRICE (X2) & 0,58 & 1,332 & Not Significant \\
\hline BRAND (X3) & 0,024 & 6,418 & Significant \\
\hline PLACE (X4) & 0,024 & 3,297 & Significant \\
\hline QUALITY (X5) & 0,177 & 2,164 & Not Significant \\
\hline PROMOTION (X6) & 0,45 & 1,469 & Not Significant \\
\hline
\end{tabular}

Table 1 shows an analysis summary of the logistic regression previously explained. The magnitude of the effect is indicated by the value of EXP (B) or also called the Odds Ratio (OR). Legal variable with OR 10,577 means that the legality of a product can influence a person's decision to buy household cleaning products as much as 10,577 times compared to products that do not have complete legality. Low prices can affect a person's decision to buy household cleaning products as much as 1,332 times more than products that are more expensive. Brand awareness of a product can affect a person's decision to buy household cleaning products as much as 6.418 times compared to products with brands that are less well known to consumers. Access, convenience and distance of shopping places can influence a person's decision to buy household cleaning products 3,297 times. The quality of product design and benefits can affect a person's decision to buy household cleaning products as much as 2,164 times. Good product promotion or advertising can influence a person's decision to buy household cleaning products as much as 2,164 times compared to products that do not have promotions and advertisements in their marketing.

Three variables (Legal, Brand, and Place) are valid and significant for purchasing decisions. Three variables (Price, Quality, and Promotion) are less significant, but this does not mean that these three variables do not affect purchasing decisions, but the effect is very small compared to other variables. The conclusion from the results of the logistic regression is that the significant variables with the highest level of influence on consecutive purchasing decisions are legality, brand and place. These three things will be the main consideration for companies that will start a business in this industry, or to improve and expand the existing company's market network. Although price, quality and promotion are not too significant compared to other variables, these three variables remain a consideration in developing company strategy.

In the previous discussion, companies are required to provide solutions to environmental problems through the development of eco-friendly products. Customer perception of eco-friendly household cleaning products is needed by the company as a consideration in its product development policy. The assessment for environmentally friendly household cleaning products in this study was divided into two parts, the first being environmental awareness (in general) and continued with preferences for environmentally friendly household cleaning products.

Table 2: Respondent Response to Environmental Awareness

\begin{tabular}{|l|c|c|c|}
\hline \multicolumn{1}{|c|}{ VARIABLES } & SCORE & $\%$ & RESULT \\
\hline $\begin{array}{l}\text { Environmental problems are } \\
\text { everyone's responsibility }\end{array}$ & 446 & $92,9 \%$ & $\begin{array}{c}\text { Strongly } \\
\text { Agree }\end{array}$ \\
\hline $\begin{array}{l}\text { Environmental problems are } \\
\text { emergency issues }\end{array}$ & 429 & $89,4 \%$ & $\begin{array}{c}\text { Strongly } \\
\text { Agree }\end{array}$ \\
\hline $\begin{array}{l}\text { My consumption activities } \\
\text { affect the environment }\end{array}$ & 381 & $79,4 \%$ & Agree \\
\hline $\begin{array}{l}\text { If everyone using eco- } \\
\text { friendly products, it can have } \\
\text { a significant effect on } \\
\text { environmental sustainability }\end{array}$ & 423 & $88,1 \%$ & $\begin{array}{c}\text { Strongly } \\
\text { Agree }\end{array}$ \\
\hline
\end{tabular}


Table 2 shows the results of the assessment of respondents' responses regarding environmental awareness. All respondents have high awareness with some conclusions as follows. Respondents realized they were partly responsible for environmental problems. Respondents have concerns that their consumption will have an impact on environmental sustainability. Respondents consider environmental problems to be addressed immediately. Respondents believe that the use of eco-friendly products collectively will support environmental sustainability.

Table 3: Respondent Response to Eco-Friendly Cleaner

\begin{tabular}{|l|c|c|c|}
\hline \multicolumn{1}{|c|}{ VARIABLES } & SCORE & \% & RESULT \\
\hline $\begin{array}{l}\text { I can easily distinguish between } \\
\text { household cleaning products } \\
\text { that are eco-friendly and that } \\
\text { are not }\end{array}$ & 292 & $60,8 \%$ & $\begin{array}{c}\text { Somewhat } \\
\text { Agree }\end{array}$ \\
\hline $\begin{array}{l}\text { I am willing to pay more to buy } \\
\text { eco-friendly household } \\
\text { cleaning products }\end{array}$ & 363 & $75,6 \%$ & Agree \\
\hline $\begin{array}{l}\text { I feel safer when buying } \\
\text { household cleaning products } \\
\text { from brands that have an eco- } \\
\text { label }\end{array}$ & 382 & $79,6 \%$ & Agree \\
\hline $\begin{array}{l}\text { I definitely chose to buy } \\
\text { household cleaning products } \\
\text { that are eco- friendly }\end{array}$ & 368 & $76,7 \%$ & Agree \\
\hline
\end{tabular}

High environmental awareness also correlates with respondents' preferences for environmentally friendly household cleaning products. Based on the results of customer analysis, all respondents considered having a preference to choose household cleaning products that are eco-friendly. However, the lack of knowledge about household cleaners that are eco-friendly makes it difficult for customers to distinguish products that are truly ecofriendly. Therefore, eco-labeling will have a good impact on customer comfort and safety.

\section{CONCLUSION}

The chemical industry, especially household cleaners, has become one of the priority sectors focused by the government based on the Making Indonesia 4.0 road map. Household growth in Indonesia for 10 years continues to increase and this trend continues until this year. Government support and the size of this market share is an opportunity for entrepreneurs in the household cleaning industry to develop. However, Indonesian law can be a barrier for small companies to compete in this market. The law that affects household cleaning products is the legality of the product, this is very important before companies market their products. the legality that must be fulfilled is the distribution permit and industrial business permit.

Conditions in the household cleaning industry still have good profitability on average but for newcomers it is quite difficult to be able to compete in this industry. Threats from new entrants and substitute products at low levels and supplier power at the middle level. However, competition and buyer power have a high level, thus reducing the level of profitability in the industry.
The legality, price, brand, place, quality and promotion of a product have a positive relationship with purchasing decisions. The results of the logistic regression table are that the significant variables with the highest level of influence on consecutive purchasing decisions are legality, brand and place. The most important factor for customers in choosing household cleaning products is legality. The legality of a product is the most significant factor compared to other factors. Another important factor after legality is the brand and place where both factors have the same influence. The conclusion is that legality, brand, and place are important factors for customers, so these three factors are priorities for companies to develop products.

The environmental awareness of the respondents was very high. Respondents feel responsible for environmental sustainability and environmental damage is a problem that must be resolved immediately. These results will have a positive impact on people's preferences in choosing products to be consumed. Almost all respondents have high awareness, but they have not been able to distinguish between household cleaning products that are eco-friendly and that are not. Even so, they are still willing to pay more to buy eco-friendly household cleaning products. The results of this analysis are that $76.7 \%$ of respondents chose to buy household cleaning products that are eco-friendly. The conclusion that eco-friendly can influence customer preferences to choose and buy these products.

\section{REFERENCES}

[1] Swift, T. Kevin, (2017). Elements of The Business of Chemistry. American Chemistry Council (ACC).

[2] Current Industry Status \& Growth Opportunities in Cosmetics and Toiletry sector. Published: Sept 30, 2019. 11:36 a.m. ET. https://www.marketwatch.com/press-release/global-householdcleaning-products-market-2019-2023current-industry-status-growthopportunities-in-cosmetics-and-toiletry-sector-expected-to-reachcagr-of-511-2019-09-30

[3] Ministry of Industry of the Republic of Indonesia (2018). Making Indonesia 4.0: RI's Strategy to Enter the 4th Industrial Revolution.

[4] Bank Indonesia. (2019). Inflation Report (Consumer Price Index) : Based on Year on Year. Retrieved https://www.bi.go.id/en/moneter/inflasi/data/Default.aspx

[5] BI Optimistic Inflation 2019 Controlled. Published: August 22, 2019. 17:23 WIB. Retrieved https://ekonomi.bisnis.com/read/20190822/9/1139850/bi-optimistisinflasi-2019-terkendali

[6] Badan Pusat Statistik. (2015). Number of Households by Province, 2000-2015. Retrieved from BPS: https://www.bps.go.id/dynamictable/2015/09/07/851/banyaknyarumah-tangga-menurut-provinsi-2000-2015.html

[7] Amaranti, Reni \& Drajat Irianto. (2017). Green Manufacturing: Literature Review, National Seminar and Conference. Surakarta, IDEC 2017 ISSN: 2579-6429.

[8] Government Regulation of the Republic of Indonesia, Number 107 of 2015, concerning Industrial Business Licenses.

[9] Ministry of Health Regulation, Number 26 of 2018, Articles 19 and 23, concerning Circulation of Medical Devices, In Vitro Diagnostic Medical Devices and Household Health Supplies.

[10]Kotler, Philip, \& Keller, K. L. (2012). Marketing Management. Edinburgh: Pearson Education 


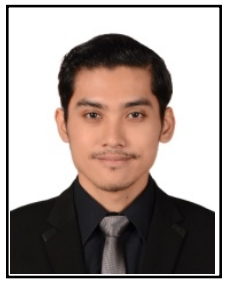

Miftah Faris was born on June 12, 1993 in West Java, Indonesia. He graduated from Brawijaya University in 2015 majoring in economics. He continued his post-graduate in Masters of Business Administration at the Bandung Institute of Technology, Indonesia, and graduated in 2020. Miftah Faris is currently an entrepreneur in the chemical industry. Currently he is active in non-profit organizations in the business sector

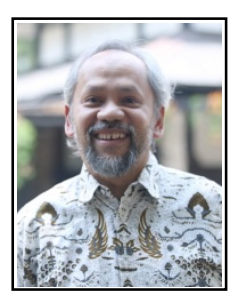

Budi Raharjo was born on October 20, 1962 in Yogyakarta, Indonesia. He completed his doctoral program at the University of Manitoba, Canada in 1996. He worked as a lecturer, entrepreneur, IT practitioner, and information security expert. Technopreneur, writer, researcher, speaker, information security consultant, blogger, are some of the professions from Ir. Budi Rahardjo, MSc, PhD. With its distinctive style, this Electrical Engineering and Master of Business Administration lecturer at ITB also contributed to the development and advancement of information technology in Indonesia. 